\title{
Role playing and emotional competence in school-age children (a causality approach)
}

\author{
Gita Romadhoni Solikhah \\ Psychology, Universitas Muhammadiyah Malang, Indonesia \\ Email: Gita.romadhoni96@gmail.com \\ Siti Suminarti Fasikah \\ Psychology, Universitas Muhammadiyah Malang, Indonesia \\ Email: Fasikhahss@yahoo.com \\ Sofa Amalia \\ Psychology, Universitas Muhammadiyah Malang, Indonesia \\ Email: $\underline{\text { S.Amalia@yahoo.com }}$
}

(Received: 06-August-2019; Reviewed: 17-September-2019; Accepted: 25-October-2019; published: 26-December-2019)

\begin{abstract}
School age is a time when the children begin to know more complex emotional expressions, so they need to learn about emotional competence to express and regulate them appropriately. One effective learning method to improve children's emotional competence is role playing. The purpose of this study was to use the role playing method to improve the emotional competence of school-age children. This study used a quasi-experimental research design of two group pretest-posttest. This study used primary-school-age population and the target population of this study was the second grade of elementary-school children. This study involved 16 participants and was divided into an experimental group and a control group. This study used an instrument to measure emotional competence. The results show significant increase on the Wilcoxon test and it can be concluded that the role-playing method can be used to improve the emotional competence of school-age children.
\end{abstract}

Keywords: School Age; Role-Playing Method; Emotional Competence; Self Adaptation.

\begin{abstract}
Abstrak:Usia sekolah merupakan masa dimana mereka mulai mengetahui ekspresi emosi yang lebih kompleks, Sehingga mereka perlu belajar tentang kompetensi emosi untuk mengekspresikan dan meregulasikan itu semua dengan tepat. Salah satu metode belajar yang efektif untuk meningkatkan kompetensi emosi anak adalah bermain peran. Tujuan dari penelitian ini adalah mengetahui metode bermain peran bisa digunakan untuk meningkatkan kompetensi emosi anak usia sekolah. Penelitian ini menggunakan desain penelitian kuasi eksperimen two grouppretest-posttest. Penelitian ini menggunakan populasi usia sekolah dasar dan target populasi penelitian ini anak kelas II sekolah dasar. Sehingga penelitian ini melibatkan 16 partisipan dan dibagi menjadi kelompok eksperimen dan kelompok kontrol. Penelitian ini menggunakan instrumen alat ukur kompetensi emosi. Hasil penelitian menunjukkan adanya peningkatan yang signifikan dari uji wilcoxon dengan nilai demikian dapat disimpulkan bahwa metode bermain peran bisa digunakan untuk meningkatkan kompetensi emosi anak usia sekolah.
\end{abstract}

Kata kunci: Usia Sekolah; Metode Bermain Peran; Kompetensi Emosi; Penyesuaian Diri. 


\section{INTRODUCTION}

The school age is in the age range of 6-12 years, a period when the children are ready for their education and development. Santrock (2012) explained that in this period, a "sense of accomplishment" emerges when the children are ready to accept the demands from others and resolve them. Emotional development according to Herlina (2013) is when children aged 7-11 years old have begun to show a variety of self-regulation skills such as regulating emotions so that the children who can adapt to the social environment well have the ability to support their emotional competence.

Denham et al. (2016) defined emotional competence as the ability to deliberately and fully express various emotions, regulate the expression of emotions, and experiences when necessary, and to understand self emotions or others'. Kilic (2015) stated that the most important component in building successful interaction to others depends on the understanding of emotions, emotional reactions, and situations. Besides, the competence is also to predict the positives such as friendship, adaptation to school, positive attitude development, attachment, and pro-social behavior.

Emotional competence is very important because children with high competence are able to interact, form relationships, and have longer relationships with others (Matute et al., 2018; Schlegel \& Mortillaro, 2019; Koivula et al., 2019; Baudry et al., 2018). Children with good emotional competence possess the characteristics of being competent in developing positive attitudes, being easy to adapt in new environments such as school, getting better grades, positive interactions with teachers, self-representation from the attachment, emotional knowledge, good emotional management skills, social skills, being accepted by their peers, being able to make and maintain friendships and being successful in academic. Whereas children who lack emotional competence will tend to be aggressive in the future, have more adaptation problems at school, risk for potential problems, difficulties in learning and at school, naughtiness, and even drug abuse in the future.

Sudarto (2018) had also evidenced this result by empirical studies supporting the importance of children's social emotional competence towards the school readiness. Here, the researcher used the role-playing method. The role-playing method is a method done by playing a role in the dramatization of social or psychological problems. Role playing has a purpose to improve the children's social emotional skills so that their language skills also increase indirectly (Claudiu \& Eduard, 2016; Zsolnail, 2015) explained that in role playing exercises, group members have the opportunity to give feedback to each other related to their training in simulation situation.

According to Uno (2007) in the role-playing method there are 7 steps, namely warming up when the teacher introduces the students to the problems for everyone to learn and master. The second step is selecting participants, the teachers and students discussing the character of each player and determining who will play it. The third step is setting the stage or place, the teachers and students discussing the place and how the role will be played and what they need. The forth is dividing the roles, the teacher offering several students role players as well as being involved in role playing. The fifth is playing the role. The sixth is discussion and evaluation, the teachers and students discussing the games and evaluating the roles. The last is sharing the experiences and conclusions. The students are invited to share their experiences about the role playing and proceed to drawing conclusions.

The researches related to children's emotional competence had been done (Maria \& Amalia, 2018; Istiqomah, Latif, \& Khutobah, 2016; Nurjannah, 2017) which focused on the social emotional development theory of resilient social emotional development characteristics in children and learning activities appropriate for children in optimizing their social emotional development in contrast to the research focusing on knowing the more complex emotional development competency, learning about emotional competence in expressing and regulating themselves properly.

\section{METHOD}

This research is a quasi-experimental study with a quantitative approach with after and before with control design or two group pretest-posttest design. The subject of this study was a population of children aged 7-8 years. This study used 8 subjects in the control group and 8 subjects in the experimental group. The characteristic of the subjects was 16 children 
who got low pretest scores in self-regulation. The measuring instrument consisted of screening questions and 16 items with a reliability index of 0.791 . The hypothesis was tested with SPSS 22 statistical analysis in the form of the Mann Whitney and Wilcoxon test to find out the difference in emotional competence before and after the role playing.

\section{RESULTS AND DISCUSSION}

The difference of the average results of the experimental group experienced an increase in empathy and sympathy, social emotion especially the attitude of mutual assistance, cooperation, rule obedience and interaction which increased from moderate to high, whereas the control group did not experience an increase in a children's emotional potential.

Table 1. The Wilcoxon Test Results of Experimental and Control Groups

\begin{tabular}{cccccc}
\hline \multirow{2}{*}{ Groups } & \multirow{2}{*}{$\mathrm{N}$} & \multicolumn{2}{c}{ Average Scores } & \multirow{2}{*}{$\mathrm{Z}$} & $\mathrm{P}$ \\
\cline { 3 - 4 } & & Pretest & Posttest & & -2.585 \\
Experimental & 8 & 27,375 & 30,875 & & 0.010 \\
Control & 8 & 26,875 & 27,375 & -1.633 & 0.102 \\
\hline
\end{tabular}

From the Wilcoxon test results in Table 1, it can be seen that $\mathrm{P}$ of the experimental group is $0.010<0.05$, meaning that there was a significant difference in the emotional competency scores of the subjects such as empathy and sympathy, mutual assistance, cooperation, rule obedience and interaction. While $\mathrm{P}$ of the control group is $0.102>0.05$, meaning that there was no significant difference in the emotional competency scores of the subjects in the pretest and posttest conditions both in experimental and control groups.

Table 2. The Mann Whitney Pretest Results of Experimental and Control Groups

\begin{tabular}{cccccc}
\hline Groups & $\mathrm{N}$ & Mean rank & Sum of Rank & $\mathrm{Z}$ & $\mathrm{P}$ \\
\hline Experimental & 8 & 9.00 & 72.00 & -0.444 & 0.657 \\
Control & 8 & 8.00 & 64.00 & & \\
\hline
\end{tabular}

Table 3. The Mann Whitney Posttest Results of Experimental and Control Groups

\begin{tabular}{cccccc}
\hline Groups & $\mathrm{N}$ & Mean rank & Sum of Rank & $\mathrm{Z}$ & $\mathrm{P}$ \\
\hline Experimental & 8 & 12.38 & 99.00 & -3.320 & 0.001 \\
Control & 8 & 4.63 & 37.00 & & \\
\hline
\end{tabular}

From Table 2, it obtained $\mathrm{P}=0.657$ (> $0.05)$. It can be concluded that no difference was significant between the experimental and control groups, indicating the same initial state given that the children did not yet understand the empathy and sympathy before the treatment. Furthermore, there was a presentation of the Mann Whitney posttest results from the experimental and control groups. From Table 3, it was obtained $\mathrm{P}=0.001$, meaning that after a given treatment to the experimental and control groups, there was a significant difference. The results of experimental group experienced a significant increase.

The results were far better on posttest, meaning that their emotional competence had changed significantly in the behavior expression became more complex, began to understand the empathy and sympathy in daily life, and interacted in two directions so that the players also could feel the emotions of the other players. This trained their emotional competence, improved their social emotion, the attitude of mutual assistance, cooperation, and rule obedience when the children directly interacted with their friends in class and played the role according to the appropriate instruction from teachers and based on the theme. While the control group, a group not given the role-playing method, the pretest and posttest results were not significantly different in the behavior expression, and they did not yet understand the empathy and sympathy.

The findings of the research were in line with Sahrah \& Yuniasanti (2018); Padmi, Dantes, \& Sutama (2014); Musi, (2017) who 
evidenced that the role-playing method used the concept of the role, meaning that the players would be aware of their different roles and thought of the their behavior as well as the other players' behavior. This rose to the emotion in every player trained to interact with their friends in the class to play a role.

The findings of the research were in line with Mariskha \& Maroh (2017); Rahmawati, (2014); Latifah (2019); Oktavianti \& Aisia (2019); Nurhasanah, Neviyarni, \& Effendi (2019) who revealed that playing a role could increase children's empathy. The method gave a positive effect when the children who were shy and low in motivation became so enthusiastic. The results of observation were conducted in four children who got 4 more points (FA, DI, BA, $\mathrm{AM})$ and were initially shy and obedient when introduced, cried and fought with their friends, and they were not shy to ask when the cycle 1 was done. Then, in the cycle 2 they were not shy but very enthusiastic. If they could play the scene, they asked and tried many novel approaches. In fact, they were impatient waiting for their turn to play a role. Then, the four children who got 3 more points (AZ, RE, AQ, $\mathrm{KH})$ were a little bit shy and too active. On pretest, they were shy to ask if they did not understand. When the cycle 2 was in progress, there was a change of those who were initially difficult to be regulated. They realized that the roles they played also affected the whole story. Thus, they patiently waited for their turn, and they were not shy anymore to ask when they did not understand the scenes or the expressions.

The researches conducted by Aulina (2018); Sopiah \& Fitria (2019) also found that role-playing method was effective to improve children's emotion and changed their emotional skills in the interaction. The children were easy to be regulated and more confident.

\section{CONCLUSIONS AND SUGGESTIONS}

The role-playing method can be used to improve the emotional competence of school-age children. The experimental group showed a score of $\mathrm{P}=0.010$, meaning that there was a change in emotional competence after the role-playing method was done in the experimental group. The children began to understand the empathy and sympathy in their daily life and interacted in two directions with their friends, so they could feel the emotions of the other players. This trained their emotional competence and increased children's social emotion ranging from the attitude of mutual assistance, cooperation, rule obedience, direct interaction with classmates and played a role according to the instructions of teachers and based on the theme. The control group showed a score of $\mathrm{P}=0.102$, meaning that there was no change in emotional competence as the children felt less empathy and sympathy emotions, still lacked mutual assistance, and showed less interaction with classmates .

The school-age children (7-8 years old) are in a transition period so that if they get good support and facilities to improve their emotional competence, they will grow up better. If the children's emotional competence is in accordance with the expectation, the children will become a new hope for the nation. Conversely, if the children have a bad emotional competence, they will tend to be aggressive and only emit negative emotions causing them to give up easily and despair, and might even be involved in criminal acts as an adult.

\section{REFERENCES}

Aulina, C. N. (2018). Pengaruh Bermain Peran terhadap Peningkatan Kemampuan Sosial Anak Usia Dini. Jurnal PG-PAUD Trunojoyo: Jurnal Pendidikan Dan Pembelajaran Anak Usia Dini, 1(1), 14-2.

Baudry, A. S., Lelorain, S., Mahieuxe, M., \& Christophe, V. (2018). Impact of emotional competence on supportive care needs, anxiety and depression symptoms of cancer patients: a multiple mediation model. Supportive Care in Cancer, 26(1), 223-230.

Claudiu, I., \& Eduard. (2016). The role of therapeutically-aimed games and stories, based on the 'total communication' concept, in socio-emotional adaption of preschool child suffering from specch deficiency/disorder. Romanian Journal Experimental Applied Psychology, 7(1), 344-348.

Denham, S., Ferrier, D., Howarth, G., \& Hemdon, B. H. (2016). The main consideration in assessing the emotional competencies of young people. Cambridge Journal of Education., 46 (3), 299-317.

Herlina. (2013). Bibliotherapy: Mengatasi Masalah Anak dan Remaja melalui Buku. Bandung: Pustaka Cendekia Utama. 
Istiqomah, N., Lathif, M. A., \& Khutobah. (2016). Peningkatan Perkembangan Sosial dan Emosional melalui Kegiatan Outbond pada Anak Kelompok B TK Asysyafa'ah Jember Tahun Pelajaran 2015/2016. Jurnal Edukasi, 14(1) 50-61.

Kilic. S. (2015). Emotional competence and emotion socialization in preschoolers: the view point of preschool teachers. Journal of Education: Theory \& Practice., 15(4), 1007-1020.

Koivula, M., Turja, L., \& Laakso, M. L. (2019). Using the Storytelling Method to Hear Children's Perspectives and Promote Their Social-Emotional Competence. Journal of Early Intervention, 1053815119880599.

Latifah L. (2019). Keefektifan Teknik Drama Segitiga Karpman untuk Meningkatkan Keterampilan Empati Siswa Sekolah Menengah Pertama. Jurnal Kajian Bimbingan Dan Konseling, 4(1), 30-36.

Maria, I., \& Amalia, E. R. (2018). Perkembangan Aspek Sosial-Emosional dan Kegiatan Pembelajaran yang Sesuai untuk Anak Usia 4-6 Tahun. Bimbingan dan Konseling, 1(2), 34-87.

Mariskha. S, \& Umaroh. (2017). Bermain peran untuk meningkatkan empati pada anak usia sekolah dasar sd "x" di samarinda (experiental method). Jurnal Motiva, 1-9.

Matute, J., Palau-Saumell, R., \& Viglia, G. (2018). Beyond chemistry: the role of employee emotional competence in personalized services. Journal of Services Marketing, 32(3), 346-359.

Musi, M. A. (2017). Kontribusi Bermain Peran untuk Mengembangkan Sosial-Emosional Anak Usia Dini. Golden Age: Jurnal Pendidikan Anak Usia Dini, 1(2).

Nurhasanah, N., Neviyarni, S., \& Effendi, Z. M. (2019). The Effectiveness of Group Counseling with Role-Playing Techniques to Increase Student Empathy. International Journal of Applied Counseling and Social Sciences, 1(1), 54-61.

Nurjannah. (2017). Mengembangkan Kecerdasan Sosial Emosional Anak Usia Dini melalui Keteladanan. Bimbingan Konseling dan Dakwah Islam, 14(1)50-61.
Oktavianti R., \& Aisia, A. (2019). Kualitas Persiapan (Perencanaan) Metode Pembelajaran Bermain Peran untuk Melatih Empati Sejarah Peserta Didik. Jurnal Halaqah, 1(3), 209-223.

Padmi, I. G. A., Dantes, N., \& Sutama, M. P. P. I. M. (2014). Efektivitas Implementasi Metode Bermain Berbantuan Media Kartu Huruf Untuk Meningkatkan Kemampuan Membaca Gambar Dan Sosial Emosional Anak. Jurnal Pendidikan Dasar Ganesha, $4(1)$.

Rahmawati A. (2014). Metode bermain peran dan alat permainan edukatif untuk meningkatkan empati anak usia dini. Jurnal Pendidikan Anak, 3(1).

Sahrah, \& Yuniasanti. (2018). Efektivitas Pelatihan Pemberian Dukungan Sosial pada Walinapi dengan Metode Bermain dan Permainan Peran. Jurnal Psikologi,45(2), 151-163.

Santrock J. W. (2012). Life Span Development (Edisi $13 \mathrm{~J}$ ). Jakarta: Erlangga.

Schlegel, K., \& Mortillaro, M. (2019). The Geneva Emotional Competence Test (GECo): An ability measure of workplace emotional intelligence. Journal of applied psychology, 104(4), 559.

Sopiah, S., \&, \& Fitria, E. (2019). Upaya Meningkatkan Kemampuan Sosial Emosional Melalui Metode Proyek Usia 5-6 Tahun Di Tk. Nurussyakirin Sindang Jaya Kabupaten Tangerang. Ceria: Jurnal Pendidikan Anak Usia Dini, 9(2), 12-21.

Sudarto, S. (2018). Peningkatan Keterampilan Sosial Melalui Bermain Peran Anak Usia 4-5 Tahun Di Tk Panca Setya. Dunia Anak. Jurnal Pendidikan Anak Usia Dini, 1(1), 50-62.

Uno. B. (2007). Model Pembelajaran Menciptakan Proses Belajar Mengajar Yang Kreatif Dan Efektif. Jakarta: Bumi Aksara.

Zsolnail. A. (2015). Kompetensi sosial dan emosional. Hungarian Research Journal., 5 (1), 1-10. 